\title{
ADMINISTRATÍVNOPRÁVNE DÔSLEDKY ÚSTAVNOPRÁVNEJ OCHRANY VÔD ${ }^{1}$
}

\author{
ADMINISTRATIVE CONSEQUENCIES \\ OF CONSTITUTIONAL REGULATION \\ OF THE PROTECTION OF WATER
}

\author{
Radomír Jakab \\ Univerzita Pavla Jozefa Šafárika v Košiciach, Právnická fakulta
}

https://doi.org/10.33542/SIC2019-1-06

\begin{abstract}
ABSTRAKT
Slovenská republika sa rozhodla chránit' vodné zdroje na jej územi formou zákazu prepravy vody cez hranice Slovenskej republiky, pričom daný zákaz bol inkorporovaný do čl. 4 ods. 2 Ústavy SR. Následne táto ústavná norma bola bližšie upravená v podobe zákona, konkrétne zmeny zákona o vodách, t.j. v administratívnoprávnom predpise. Ciel'om tohto príspevku je analyzovat' a posúdit' spôsob, ako aj dôsledky úpravy ústavného zákazu prepravy vôd cez hranice štátu $v$ administratívnoprávnych normách; a zároveň poukázat' na prípadné nedostatky takejto administratívno-právnej úpravy.
\end{abstract}

\begin{abstract}
The Slovak Republic has decided to protect water resources on its territory by prohibiting the transport of water across the border of the Slovak Republic, while the prohibition being incorporated into Art. 4 ods. 2 of the Constitution of the SR. Subsequently, this constitutional norm was further regulated in the form of an ordinary law, in the form of amendment to the Water Act. The aim of this contribution is to analyze and assess the way and the consequences of the regulation of the constitutional prohibition of transport of water across borders in administrative norms; while pointing to the possible discrepencies of such administrative regulation.
\end{abstract}

\section{I. ÚVOD}

Dňa 1.12.2014 nadobudol účinnost' ústavný zákon č. 306/2014 Z.z. ktorým sa dopĺn̆a Ústava Slovenskej republiky č. 460/1992 Zb. v znení neskorších predpisov; týmto ústavným zákonom došlo k doplneniu čl. 4 ods. 2 Ústavy Slovenskej republiky (d’alej len „Ústava SR“). Podl'a tohto ustanovenia ,preprava vody odobratej z vodných útvarov nachádzajúcich sa na území Slovenskej republiky cez hranice Slovenskej republiky dopravnými prostriedkami alebo potrubím sa zakazuje; zákaz sa nevzt’ahuje na vodu na osobnú spotrebu, pitnú vodu balenú do spotrebitel'ských obalov na území Slovenskej republiky a prírodnú minerálnu vodu balenú do spotrebitel'ských obalov na území Slovenskej republiky a na poskytnutie humanitárnej pomoci a pomoci v núdzových stavoch. Podrobnosti o podmienkach prepravy vody na osobnú spotrebu a vody na poskytnutie humanitárnej pomoci a pomoci v núdzových stavoch ustanoví zákon.“”

\footnotetext{
Tento príspevok vznikol s podporou a je výstupom riešenia výskumného projektu APVV-16-0362 „Privatizácia trestného práva - hmotnoprávne, procesnoprávne, kriminologické a organizačno-technické aspekty“.
} 
Z daného ustanovenia Ústavy SR je možné vyvodit’ všeobecný zákaz prepravy vody odobratej z vodných útvarov nachádzajúcich sa na území Slovenskej republiky cez jej hranice dopravnými prostriedkami alebo potrubím. Podl'a dôvodovej správy k návrhu novelizácie Ústavy SR vodnými útvarmi nachádzajúcimi sa na území Slovenskej republiky sa rozumejú všetky zdroje vôd, a to podzemné vody, prírodné minerálne zdroje, prírodné liečivé zdroje, geotermálne vody a tiež povrchové vody, teda vodné toky, vodné nádrže a vodárenské nádrže, kanále, jazerá a pod. Dané ustanovenie Ústavy SR sa teda vzt’ahuje na všetky kategórie vôd odobraté z vodných útvarov na území Slovenskej republiky.

Podl'a čl. 4 ods. 2 druhej a tretej vety Ústavy SR zákaz sa nevzt'ahuje na vodu na osobnú spotrebu, pitnú vodu balenú do spotrebitel'ských obalov na území Slovenskej republiky a prírodnú minerálnu vodu balenú do spotrebitel’ských obalov na území Slovenskej republiky a na poskytnutie humanitárnej pomoci a pomoci $\mathrm{v}$ núdzových stavoch. V danom článku je umožnené stanovovat' bližšie podmienky prepravy vo forme zákona iba v prípade vody na osobnú spotrebu, vody na poskytnutie humanitárnej pomoci a pomoci v núdzových stavoch. Tieto podmienky sú tak špecifikované v ust. § 17a zákona č. 364/2004 Z.z. o vodách a o zmene zákona Slovenskej národnej rady č. 372/1990 Z b. o priestupkoch v znení neskorších predpisov (vodný zákon) v znení neskorších predpisov (d’alej len „zákon o vodách“).

Vo vzt'ahu k pitnej vode balenej do spotrebitel'ských obalov na území Slovenskej republiky, ako aj vo vzt'ahu k prírodnej minerálnej vode balenej do spotrebitel'ských obalov na území Slovenskej republiky je daná celková exempcia zo zákazu prepravy cez hranice. Ide teda o výnimku na prepravu vody spracovanej na území Slovenskej republiky, ktorá je dodávaná do obchodnej siete a na ktorú sa vzt’ahuje režim čl. 34 a 35 Zmluvy o fungovaní Európskej únie. Táto výnimka sa vzt'ahuje tak na prepravu vody pre súkromné účely, ako aj pre obchodné účely.

V súvislosti s prijatím danej ústavnej zmeny vyvstali otázky, do akej miery môže členský štát Európskej únie autonómne stanovovat' reštrikcie vo vzt’ahu $\mathrm{k}$ uplatňovaniu vol'ného pohybu tovaru, ktorým, za určitých okolností, voda je. Dokonca, v súvislosti s prijatím danej zmeny Ústavy SR bolo vo vzt’ahu k Slovenskej republike začaté konanie pre porušenie práva Európskej únie. Limitmi ústavnoprávnej ochrany vôd s prihliadnutím aj na právo Európskej únie som sa zaoberal $\mathrm{v}$ rámci môjho príspevku ${ }^{2}$ na medzinárodnej vedeckej konferencii „25. rokov Ústavy Slovenskej republiky - Ústavné dni“ konanej v dňoch 26. a 27.9.2017 v Košiciach. ${ }^{3}$

Ciel'om tohto príspevku je analyzovat' a posúdit' spôsob, ako aj dôsledky úpravy ústavného zákazu prepravy vôd cez hranice štátu $\mathrm{v}$ administratívnoprávnych normách; a zároveň poukázat' na prípadné nedostatky takejto administratívno-právnej úpravy.

\section{NIE JE ZÁKONNÁ ÚPRAVA REŠTRIKTÍVNEJŠIA AKO ÚPRAVA V ÚSTAVE SR?}

Ako bolo vyššie uvedené, zákaz prepravy vody cez hranice štátu je upravený v čl. 4 ods. 2 Ústavy SR. Okrem zákazu, v tomto ustanovení je upravená aj výnimka z tohto zákazu, a to že „zákaz sa nevzt’ahuje na vodu na osobnú spotrebu, pitnú vodu balenú do spotrebitel'ských obalov na území Slovenskej republiky a prírodnú minerálnu vodu balenú do spotrebitel'ských obalov na území Slovenskej republiky a na poskytnutie humanitárnej pomoci a pomoci v

JAKAB, R. Ústavnoprávna ochrana vôd a jej limity. In OROSZ, L. GRABOWSKA, S., MAJERČÁK, T. (ed): Ústavné dni - 25. Výročie Ústavy Slovenskej republiky - VI ústavné dni. Košice, UPJŠ v Košiciach, 2018, 349 - 356 s.

3 K tomu tiež BALOG, B.: Ochrana vody ako výzva (aj) pre konštitucionalizmus alebo o tom, ako sa potrubie do ústavy dostalo. In Weyrovy dny právní. Teorie 2016. Brno: Masarykova univerzita, Pravnicka fakulta, 2016, ISBN: 978-80-2109364-6, s. 100 - 118; MASLEN, M.: Právna úprava starostlivosti o vody v Slovenskej republike. Praha: Leges, 2017, ISBN: 978-80-7502-193-9. 
núdzových stavoch. Podrobnosti o podmienkach prepravy vody na osobnú spotrebu a vody na poskytnutie humanitárnej pomoci a pomoci v núdzových stavoch ustanoví zákon.“

Ústava SR v tomto ohl'ade odkazuje na zákonnú úpravu, ktorá bude upravovat' podrobnosti o podmienkach prepravy vody na osobnú spotrebu a vody na poskytnutie humanitárnej pomoci a pomoci v núdzových stavoch.“ Táto úprava je v ust. § 17a zákona o vodách. Podl’a odseku 1 tohto ustanovenia „Využívanie vody odobratej z vodných útvarov nachádzajúcich sa na území Slovenskej republiky na prepravu dopravnými prostriedkami alebo potrubím cez hranice Slovenskej republiky sa zakazuje okrem prípadov uvedených v odsekoch 2 až 5." Podl'a znenia ods. 2 tohto ustanovenia „Preprava vody odobratej z vodných útvarov nachádzajúcich sa na území Slovenskej republiky cez hranice Slovenskej republiky je možná len na osobnú spotrebu a na poskytnutie humanitárnej pomoci a pomoci v núdzových stavoch.“

Zákon o vodách v ust. $§ 17 \mathrm{a}$ ods. 1 stanovuje zákaz prepravy vôd cez hranice štátu, pričom tento zákaz je rovnaký, ako v čl. 4 ods. 2 Ústavy SR. V odseku 2 upravuje výnimky z tohto zákazu, a to využitie vody pre osobnú spotrebu a na poskytnutie humanitárnej pomoci a pomoci v núdzových stavoch. V ust. $§ 17$ a však nie je upravená výnimka zo zákazu prepravy, a to, že zákaz sa nevzt'ahuje taktiež na pitnú vodu balenú do spotrebitel'ských obalov na území Slovenskej republiky a prírodnú minerálnu vodu balenú do spotrebitel'ských obalov na území Slovenskej republiky. Takáto výnimka zo zákazu je však upravená v čl. 4 ods. 2 Ústavy SR. Na základe toho je možné konštatovat', že zákonná úprava v ust. $§ 17$ a zákona o vodách stanovuje menší rozsah výnimiek zo zákazu prepravy vody cez hranice štátu v porovnaní s úpravou v čl. 4 ods. 2 Ústavy SR. Teda, úprava v ust. § 17a ods. 1 a 2 nie je súladná s čl. 4 ods. 2 Ústavy SR, dokonca je reštriktívnejšia.

\section{VZŤAHUJE SA ZÁKONNÁ ÚPRAVA ZÁKAZU PREPRAVY VÔD NA VŠETKY DRUHY VÔD?}

Vychádzajúc z dôvodovej správy návrhu ústavného zákona č. 306/2014 Z.z. ústavný zákaz sa mal vzt'ahovat' na všetky kategórie vôd odobratých z vodných útvarov na území Slovenskej republiky. Vodnými útvarmi nachádzajúcimi sa na území Slovenskej republiky sa, podl’a dôvodovej správy, rozumejú všetky zdroje vôd, a to podzemné vody, prírodné minerálne zdroje, prírodné liečivé zdroje, geotermálne vody a tiež povrchové vody, teda vodné toky, vodné nádrže a vodárenské nádrže, kanále, jazerá a pod.

V tejto súvislosti vyvstáva otázka, či zákonná úprava reflektuje ústavnú úpravu, t.j. že zákaz sa má vzt'ahovat' na všetky vodné útvary nachádzajúce sa na území Slovenskej republiky, t.j. na všetky kategórie vôd. Ako už bolo uvedené, zákonná úprava je obsiahnutá v ust. $§ 17 \mathrm{a}$ zákona o vodách. Pri hl'adaní odpovede na nastolenú otázku je potrebné vziat' do úvahy aj znenie ust. $\S 3$ ods. 5 zákona o vodách. Podl'a tohto ustanovenia „Na vody, ktoré sú vyhlásené za prírodné liečivé zdroje a za prírodné zdroje minerálnych stolových vôd podla osobitného predpisu, a na vody, ktoré sú vyhradenými nerastmi podl'a osobitného predpisu (d’alej len „osobitné vody“"), sa tento zákon vzt’ahuje, len ak to výslovne ustanovuje.“"

Ak sa má ust. § 17a zákona o vodách vzt’ahovat' aj na tzv. osobitné vody, potom je nevyhnutné, aby to bolo explicitne uvedené v zákone o vodách. Je však možné konštatovat', že zákon o vodách výslovne nestanovuje (ani v ustanovení $§ 17 \mathrm{a}$, ako ani v inom ustanovení), že zákaz prepravy vody podl'a ust. § 17 a sa vzt’ahuje aj na osobitné vody, t.j. na vody vyhlásené za prírodné liečivé zdroje a prírodné zdroje minerálnych vôd, ako aj na vody, ktoré sú vyhradenými nerastami.

Na základe toho je možné vyvodit', že z hl'adiska jazykového výkladu zákonná úprava nie je totožná s ústavnou úpravou ani v rozsahu kategórií vôd, na ktoré sa má zákaz prepravy cez hranice štátu vzt’ahovat'. Zákonná úprava je v tomto ohl'ade užšia, nezohl'adňujúca všetky druhy vôd, t.j. nevzt'ahuje sa na tzv. osobitné vody. Prekonat' tento nesúlad je možné iba aplikovaním 
ústavne-konformného výkladu podl’a čl. 152 ods. 4 Ústavy SR, ako aj teleologického výkladu berúc do úvahy vôlu zákonodarcu v intenciách dôvodovej správy. No každopádne, princíp právnej istoty by si vyžadoval, aby právne normy boli dostatočne jasné a určité.

\section{VZŤAHUJE SA ZÁKAZ PREPRAVY AJ NA UŽ POVOLENÉ ODBERY VÔD?}

Ďalšou problematickou oblast'ou je posúdenie, či zákaz prepravy vôd cez hranice štátu sa vzt'ahuje aj na také odbery vôd, ktoré už boli povolené v minulosti, a ktoré umožňovali prepravu vôd cez hranice štátu. Ústava SR nemá ustanovenie, ktoré by osobitne riešilo daný prípad (napr. v prechodnom ustanovení). Vychádzajúc z toho je možné konštatovat', že ústavný zákaz sa má vzt'ahovat' na akúkol'vek prepravu vody cez hranice štátu, a to počnúc účinnost'ou ústavnej zmeny (1.12.2014), a to bez ohl'adu na to, či takáto preprava bola predtým povolená alebo nie.

Na druhej strane, odchýlnu úpravu riešenia vyššie uvedeného problému obsahuje ust. § 80d ods. 3 zákona o vodách. Podl'a tohto ustanovenia „Práva a povinnosti vyplývajúce z povolení a rozhodnutí vydaných do 14 . januára 2015, ktoré nie sú v súlade so zákonom účinným od 15 . januára 2015, je potrebné do 31. decembra 2018 uviest' s ním do súladu, inak povolenia a rozhodnutia strácajú platnost'.“ Podl'a tohto ustanovenia, ak na základe predchádzajúceho povolenia alebo rozhodnutia bola povolená preprava vody cez hranice štátu, takúto prepravu je možné nad'alej vykonávat' až do 31.12.2018. Ak dovtedy nebude vykonaná zmena povolenia alebo rozhodnutia, tak strácajú zo zákona platnost'.

Domnievam sa, že ak podl'a Ústavy SR nie je možná preprava vody cez hranice štátu počnúc 1.12.2014, zákon nemôže stanovit’ neskorší termín uplatňovania tohto zákazu. Zákonná úprava musí byt' aj v tomto ohl'ade v súlade $\mathrm{s}$ ústavnou úpravou.

$\mathrm{Z}$ rovnakých dôvodov, aké boli uvedené v časti III tohto príspevku, ust. § 80d ods. 3 zákona o vodách by sa $z$ hl'adiska jazykového výkladu taktiež nemalo vzt'ahovat' na osobitné vody, ked’že absentuje výslovná zmienka, že sa má vzt'ahovat' aj na rozhodnutia a povolenia týkajúce sa osobitných vôd. Aj v tomto prípade je potrebné aplikovat' ústavne-konformný výklad na to, aby sa aj toto ustanovenie vzt'ahovalo na osobitné vody, čo bol aj ciel' zákonodarcu (vychádzajúc z dôvodovej správy k návrhu novely Ústavy SR).

\section{JE VYMEDZENIE VÝNIMKY ZO ZÁKAZU PREPRAVY VODY PRE OSOBNÚ SPOTREBU DOSTATOČNE URČITÉ?}

Podl'a ust. $§ 17 \mathrm{a}$ ods. 3 zákona o vodách „Preprava vody odobratej z vodných útvarov nachádzajúcich sa na území Slovenskej republiky cez hranice Slovenskej republiky na osobnú spotrebu je možná na použitie na pitné účely v objeme najviac 20 litrov na osobu. “ Tým zákonodarca špecifikoval, za akých podmienok je možné uplatnit’ výnimku zo zákazu prepravy vody cez hranice štátu pre osobnú spotrebu. No v súvislosti s interpretáciou tohto ustanovenia vyvstáva viacero otázok. Vzt’ahuje sa stanovený limit na jednorazové prekročenie hranice, či aj na viacnásobné? Ak ide o viacnásobné, potom za aké obdobie? Je vhodné limitovat' túto výnimku iba pre pitné účely? Akým spôsobom bude kontrolované dodržiavanie uplatňovania tejto výnimky? A akým spôsobom bude sankcionované porušenie tejto výnimky?

Je možné súhlasit's názorom R. Krála, že ,aj ked’ prevozy vody v objeme 20 litrov na jednu osobu nemusia pôsobit' dramaticky, zákonodarca mohol tieto limity v záujme jasnosti a zrozumitel'nosti spresnit'. Navrhovaným riešením by mohlo byt' vzt'ahovanie limitu 20 litrov na osobu (pre pitné účely) na jeden deň aj pri viacnásobnom prekročení štátnej hranice. Takéto riešenie by, $v$ kontexte biologických potrieb jednej osoby na jeden deň, zodpovedalo myšlienke využitia prepravovanej vody na pitné účely. $\mathrm{Na}$ druhej strane však, takáto idea naráža na zložitost' a administratívnu náročnost' kontroly dodržiavania takéhoto obmedzenia zo strany 
kontrolných orgánov. Táto skutočnost' súvisí aj s faktom, že miera pravidelných, resp. stálych hraničných kontrol na hraničných priechodoch sa v podmienkach Slovenskej republiky našim vstupom do Schengenského priestoru významne obmedzila. Terajšia zákonná úprava je však nejasná a v praxi $\mathrm{v}$ podstate nepoužitel'ná, nesmerujúca $\mathrm{k}$ naplneniu účelu a žiada si precizovanie. ${ }^{\text {“4 }}$ Okrem toho kontrolu by mali vykonávat’ orgány štátnej vodnej správy v rámci štátneho vodoochranného dozoru ${ }^{5}$; je len t’ažko predstavitel'né, aby dokázali personálne zabezpečit' takúto kontrolu po celej dĺžke štátnej hranice.

Okrem množstevného limitu uplatnenie výnimky vyžaduje aj dodržanie účelu využitia vody výlučne na pitné účely. Taktiež sa stotožňujem s názorom R. Krála, že „pod termínom voda na osobnú spotrebu, ktorý okrem vodného zákona používa aj Ústava, by malo byt' zahrnuté, okrem využitia vody na pitné účely, aj využitie vody na osobnú hygienu. Takto rozšírené účelové využitie vody na osobnú spotrebu nachádzame aj v dokumentoch medzinárodných organizácií, napr. Organizácie spojených národov ${ }^{6}$."7

A napokon domnievam sa, že aj vyvodzovanie administratívno-právnej zodpovednosti za porušenie podmienok prepravy vody cez hranice štátu pre osobnú spotrebu nie je ideálne nastavené. $\mathrm{V}$ ust. $\S 74$ ods. 1 písm. n) zákona o vodách je upravený správny delikt, podl'a ktorého „orgán štátnej vodnej správy uloží pokutu právnickej osobe alebo fyzickej osobe podnikatel'ovi, ktorá prepraví vodu odobratú z vodných útvarov nachádzajúcich sa na území Slovenskej republiky cez hranice Slovenskej republiky v rozpore s $\S 17$.“ Podl'a ust. $§ 75$ ods. 10 zákona o vodách ,ppokutu podl'a $§ 74$ ods. 1 písm. n) možno uložit’ od 33000 eur do 100000 eur; súčasne sa zruší povolenie na užívanie vôd.“

Teda, za uvedený správny delikt sú postihnutel'né právnické osoby a fyzické osoby podnikatelia. No porušenie ust. § 17a zákona o vodách nie je vymedzené ako priestupok v rámci ust. $§ 77$ tohto zákona, upravujúceho priestupky na úseku vodného hospodárstva. Teda, porušenie ust. § 17a zákona o vodách nie je sankcionovatel'né voči fyzickým osobám (s výnimkou podnikatel'ov). Pričom nedodržanie limitov prepravovanej vody pre osobnú spotrebu, ako aj jej určenie na pitné účely sa môže (a aj bude) týkat' fyzických osôb. Z tohto pohl'adu mám za to, že právna úprava nie je dostatočne dôsledná.

\section{ZÁVER}

S účinnost'ou od 1.12.2014 došlo k doplneniu čl. 4 Ústavy SR o odsek 2 upravujúci zákaz prepravy vody z vodných útvarov na území Slovenskej republiky cez jej hranice, pričom boli stanovené výnimky $\mathrm{z}$ tohto zákazu. Táto ústavná norma bola následne detailizovaná $\mathrm{v}$ bežnom zákone, konkrétne v ust. $\S 17 \mathrm{a}$ zákona o vodách. No domnievam sa, že zákonodarca nebol dostatočne dôsledný pri prijímaní tejto úpravy.

V prvom rade, v ust. § 17a zákona o vodách je síce zopakovaný (hoci nadbytočne) zákaz prepravy vody, no v d’alšom neboli poskytnuté všetky výnimky, ktoré poskytuje samotná ústava (že zákaz sa nevzt’ahuje na pitnú vodu balenú do spotrebitel'ských obalov na území Slovenskej republiky a prírodnú minerálnu vodu balenú do spotrebitel'ských obalov na území Slovenskej republiky). Z tohto pohl'adu je zákonná úprava reštriktívnejšia v porovnaní s ústavnou úpravou.

Okrem toho, podl'a ústavnej úpravy sa mal zákaz vzt’ahovat’ na všetky kategórie vôd. Zákonodarca pri prijímaní zmeny zákona o vodách (ust. § 17a) nezohl'adnil ust. § 3 ods. 5 tohto zákona, podl'a ktorého sa zákon o vodách vzt'ahuje na tzv. osobitné vody iba vtedy, ak to

KRÁL, R.: Ústavný zákaz vývozu vody cez hranice Slovenskej republiky. In Justičná revue, 2016, č. 2, s. 140.

Bližšie k orgánom štátnej vodnej správy in. TEKELI, J.: 11. Správa vodného hospodárstva. In. TEKELI, J. a kol. Správne právo hmotné. Osobitná čast'. Košice: Univerzita Pavla Jozefa Šafárika v Košiciach, Právnická fakulta. 2017, ISBN: 97880-8152-561-2, s. 162-163.

6 Napr. Rezolúcia Rady Organizácie spojených národov pre l’udské práva č. 15/9 z roku 2010.

7 KRÁL, R.: Ústavný zákaz vývozu vody cez hranice Slovenskej republiky. In Justičná revue, 2016, č. 2, s. 140. 
výslovne stanovuje. No v ust. § 17a zákona, ako ani v inom, nie je uvedené, že ust. § 17a sa má vzt'ahovat' aj na osobitné vody. Formálnym výkladom teda možno dospiet' k tomu, že zákonná úprava zákazu prepravy vody cez hranice štátu sa nevzt'ahuje na osobitné vody. Túto nedôslednost' je možné zhojit' jedine ústavne-konformným výkladom.

Článok 4 ods. 2 Ústavy SR, upravujúci zákaz prepravy vody cez hranice štátu, vstúpil do účinnosti dňa 1.12.2014. Teda počnúc týmto dňom preprava vody cez hranice štátu bola zakázaná. No v ust. $§ 80 d$ ods. 3 zákona o vodách bolo upravené, že práva a povinnosti vyplývajúce z povolení a rozhodnutí vydaných do 14 . januára 2015 , ktoré nie sú v súlade so zákonom účinným od 15. januára 2015, je potrebné do 31. decembra 2018 uviest' s ním do súladu; inak také povolenia a rozhodnutia strácajú platnost'." Ak sa teda umožnilo, na základe povolení a rozhodnutí dovtedy vydaných, prepravovat' vodu mimo územie štátu, bolo možné tak postupovat' aj nad'alej, najdlhšie do 31. decembra 2018. Inak povedané, podl'a čl. 4 ods. 2 Ústavy SR nie je možné prepravovat' vodu cez hranice štátu od 1. decembra 2014, no na základe ust. $\S 80$ d ods. 3 zákona o vodách bolo možné ju prepravovat' až do 31. decembra 2018. Aj v tomto ohl'ade je možné identifikovat' disenzus medzi zákonnou a ústavnou úpravou.

A napokon, aplikačné problémy spôsobuje uplatňovanie výnimky zo zákazu prepravy vody cez hranice štátu pre osobnú spotrebu, ktorú zákonodarca vymedzil v rozsahu 20 litrov a len na pitné účely. Je teda diskutabilné, či množstevný limit sa vzt’ahuje na jednorazové prekročenie hranice, alebo viacnásobné; ak viacnásobné, tak nie je zrejmé v akom časovom období. Okrem toho, zúženie osobnej spotreby iba na pitné účely tiež nie je vhodné. Problematická je aj možnost' kontrolovatel'nosti dodržiavania týchto podmienok z dôvodu absencie stálych kontrol na hraniciach; a obzvlášt' ak kontrolu by mali vykonávat' orgány štátnej vodnej správy. V súvislosti s uplatnením tejto výnimky je taktiež problematické vyvodzovanie administratívno-právnej zodpovednosti v prípade porušenia stanovených podmienok. Zákon síce vymedzuje správny delikt spočívajúci v porušení ust. $§ 17 \mathrm{a}$, no toho sa môžu dopustit' len právnické osoby a fyzické osoby - podnikatelia. Porušenie ust. § 17a zákona o vodách nie je však vymedzené ako priestupok, ktorého by sa mohli dopustit' fyzické osoby (aj bez statusu podnikatel').

Na základe toho je možné konštatovat', že zákonodarca nebol dostatočne dôsledný pri prijímaní zákonnej právnej úpravy, ktorá by bližšie upravovala podmienky uplatnenia výnimiek zo zákazu prepravy vody cez hranice štátu v intenciách čl. 4 Ústavy SR.

\section{KLÚČOVÉ SLOVÁ}

ochrana vôd, preprava vody cez hranice štátu

\section{KEY-WORDS}

Water protection, transport of water across borders of state

\section{POUŽITÁ LITERATÚRA}

1. BALOG, B.: Ochrana vody ako výzva (aj) pre konštitucionalizmus alebo o tom, ako sa potrubie do ústavy dostalo. In Weyrovy dny právní. Teorie 2016. Brno: Masarykova univerzita, Pravnicka fakulta, 2016, ISBN: 978-80-210-9364-6, s. $100-118$.

2. ČECHMÁNEK, K.: Právo na vodu v politickom a právnom kontexte. In Justičná revue, 2015, č. 2, s. $156-169$.

3. JAKAB, R. Ústavnoprávna ochrana vôd a jej limity. In OROSZ, L. GRABOWSKA, S., MAJERČÁK, T. (ed): Ústavné dni - 25. Výročie Ústavy Slovenskej republiky - VI ústavné dni. Košice, UPJŠ v Košiciach, 2018, 349 - 356 s. 
4. MASLEN, M.: Právna úprava starostlivosti o vody v Slovenskej republike. Praha: Leges, 2017, ISBN: 978-80-7502-193-9, s. 112.

5. KRÁL, R.: Ústavný zákaz vývozu vody cez hranice Slovenskej republiky. In Justičná revue, 2016, č. 2, s. 137-147.

6. PALÚŠ, I. Ústava Slovenskej republiky ako základ transformácie spoločnosti a štátu, In: Acta Iuris Cassoviensia, Právnická fakulta UPJŠ Košice, 1999.

7. TEKELI, J. a kol. Správne právo hmotné. Osobitná čast'. Košice: Univerzita Pavla Jozefa Šafárika v Košiciach, Právnická fakulta. 2017, ISBN: 978-80-8152-561-2, s. 294.

8. TOMÁŠEK, M. - TÝC̆ V. a kol.: Právo Evropské unie; 1. vydanie, Praha: Leges, 2013, ISBN: 978-80-87576-53-3, s. 494.

\section{KONTAKTNÉ ÚDAJE AUTORA}

doc. JUDr. Radomír Jakab, PhD.

docent na Katedre ústavného práva a správneho práva

Univerzita Pavla Jozefa Šafárika v Košiciach, Právnická fakulta

Kováčska 26, 04001 Košice, Slovenská republika

E: radomir.jakab@upjs.sk 